\title{
Political Changes in Rural West Bengal A Heuristic Discussion on Rajoor Gram Panchayat in Bardhaman
}

\author{
DR. Sujit Narayan Chattopadhyay \\ And \\ Surjasnata Chattopadhyay
}

\begin{abstract}
This paper presents a heuristic attempt for understanding the political change in villages in West Bengal. Attempts have been made to illustrate several important facts to the study of possibilities of and limit to the changes now being seen in West Bengal villages. The primary focus is on the significance of this narrative for an understanding of general historical background to the post nineties experience. We have, in our study, tried to indicate some aspects of changes but it is evident that those are not merely the one way process -- a simple mobilization of the top.
\end{abstract}

\section{INTRODUCTION:}

Once, at the beginning of this century, a question was often asked, "What actually explains the extraordinary stability for a period over three decades of Left Front rule in West Bengal?" But that question has changed its basic direction of its thrusting zone. Pervaded left dominance of more than three decades gradually, but decidedly and silently tumbled down by a pressure of dissident part of the hostile anti left rightist party. This paper, specially based on close observation of five Gram Panchayat of Bardhhaman District of West Bengal, followed by the observations made in different literatures on West Bengal village politics. In view of that we have tried to find out the institutional effectiveness of the structure of village government and mobilization of vote politics to bring change of the basic pattern of Power in the State government. Secondly an attempt has made to understand, how the clientelism, formed by the Left Front Government during its rule of more than three decades has poured by the hostile anti left Rightist force breaking the long time dependence of the supporters. Several studies have so far tried to explain this facts by presenting nuanced data 'Nandigram', 'Singur' or 'Netai' incidents to explain the causes of the shifting and erosion of supporters of Rural Bengal. But our question is different. We have tried here to find out the reasons which were spouted internally to the institution of government and within the circle of party control that ultimately engendered the stability of the Left Government as well as Left Front parties.

Our experience of this political change is based on our observation of 'Rajoor Gram Panchayet' consisting of seven villages - Argon, Bahara, Khanji, Khaspur, Masundi, Raikha and Rajoor - scattered over an area of 2673.31 Sq.Km., is situated in Katwa Subdivision under the jurisdiction of Ketugram Police Station. Rajoor Gram Panchayet is not a revenue village or Mouza. It is included within the Gyandaskhandra Block for Revenue purpose. We came to know about the dramatic changes that happened during last few decades. We experienced this dramatic political change, when we revisited the place in $20^{\text {th }}$. May to $1^{\text {st }}$.June 2013 , we left on $2^{\text {nd }}$. June ' 13 , because the Panchayat election process of 2013 started from $29^{\text {th }}$. May 2013, (I first visited the place in 1984-1986, (when I was working on Doctoral project on "Changes of Dominance in Rural West Bengal") ${ }^{(1)}$. The existing form of Panchayat based political dominance led by politically and ideologically tinged Parties stared from late 70's of the last century. The uniqueness of that was the general participation of common men in the arena of political and administrative decision making process. Democratization of Panchayet election played the role of a catalyst to envelope the entire village under the fold of power oriented "election politics". This actually brought down the shackles of the dominance of big-men politics. At the same time, the entry of participatory politics in village through Panchayet, common and subaltern villagers started to recognize their importance as determinant of larger domain of West Bengal politics. This extended importance 
of villagers in the larger domain of State Politics has brought about a perceivable change in the structure of socio-political relation in the village society.

Of course this 'structural change' did not come independently from social and political reality. Part of the basis of this change was laid in the 70's and 80's decade of the last century. How much of these changes can we attribute to internal economic or political dynamics? Or, how much was the result of intervention by forces (of political parties or State agencies) from outside the village, operating in the larger domain of West Bengal politics? These are the questions we have often referred to in the course of our narratives.

\section{Looking through the Class.}

There are certain recognized frameworks for understanding these perceivable changes of villages. One of such concept is Class and Class Struggle. This model is used by Social Scientists interested to understand changes in the structure of political authority and mobilization. The decline of old form of authority and process of mobilization started with the abolition of Zamindari System, but it got a new momentum in late 70's and early 80's of the last century, when Panchayati System peeked up its activities with three tier structures.

One thing should be mentioned here. The implementation of the Estate Acquisition Act 1953, ${ }^{(2)}$ created a new tendency of partitioning of landed property among the members of the family. This ultimately resulted the fragmentation of landholding as well as it created a tendency among most of younger members of the erstwhile 'big families' to seek better comfortable and service oriented secured life outside the villages. Thus the migrating to city or town gradually become a general vision to the younger generation. This tendency gradually brought a crack in their family solidarity and their social acceptability as 'big wealthy' families. This creates a new scope for coming up a new social and political leadership to fill up the gap created by the fragmentation of the big families A new type of Socio-Political leadership started to get a gradual and steady shape since $70^{\prime}$ and $80^{\prime}$ of the last century. Here the role of Kishan Sabha or local political party units and their continuous contiguousness with lower middle class cultivating landowners, share croppers and land less laborers cannot be denied. Even before that, there were a few occasions when landless laborers came into direct conflict with upper class landowners. During the period of our initial visit of the place during 80 's of the last century, we were told some incidents of forcible occupation of land by the share croppers or the attempt to thresh paddy in the sharecroppers' yard show a clear departure from the traditional attitude of subordination of the lower class people. Although, during late 65 to 70's of the last century, there was panchayet, and they even were supported by some new band of growing leadership, yet the actual justice to their demands were virtually denied. But at that point of time they were at first introduced to an entirely new leadership, so far unknown to them, who learnt them to a new form of protest and also show them the advantage of relying on advice, guidance and organizational skill. Also they felt the dim presence of the State in support of their movements, which was so far unknown to them. But the leadership under which they raised their voice, was not stemmed from their own class. Even then they were prepared to join with them in their struggle against their dominators. But this was not a temporary alliance based on the generosity of these band of new generation leaders at any particular agenda of protest. Rather with the implementation of amended three tier Panchayati system in villages since 1977, this became a regular ideologically commitment and institutionalized process of relation between leaders and supporters within a political party. It was wholly a new feature of village politics, and institutional structure. This assertion of lower classes was greatly extended and intensified not only in Rajoor Gram Panchayet area but also in other Panchayet areas in West Bengal, especially in Bardhhaman District. Between the end of 70's and 80's decades of last century the class antagonism in different village panchayet were open, continuous and often violent. A new brand of leadership, under the shadowy shelter of higher level party leadership, played a crucial role in this phase. During that time we witnessed that a large section of middle class of villages, small property owners, coming from upper and middle class were annoyed with the new leaders, because of this politics of 'mounting confrontation'. The initiation and consolidation of organized party politics through popularly elected Panchayet System or structure brought about a basic change in the nature of demands and methods of organization of lower class people. We can definitely notice here a serious political organization on the basis of class demands. But at the same time we cannot say that this class assertion has in any way brought about a fundamental change in the existing production relation in villages of West Bengal. Even now the disproportionate distribution of 
landownership still persists along with a class of Non-Cultivating owners who mainly cultivate their lands either by "Munish /Mahinder" or by the sharecroppers whether recognized as bargadars or not. Even during our recent visit of Rajoor Gram Panchayet area, we have not seen any major changes in the traditional pattern of dependence of the cultivators on their landowners. Especially during the lean period the cultivators, marginal landowner cultivators and landless cultivators, heavily depend on their landowner for crop-advance. Apart from that, at present a large number of landless cultivators still look towards the landowners for supplying of other means of production, like plough, bull and fertilizers. Even they look for monetary support for irrigation water from shallow or for hiring bunk tickets in Cold Storage. Thus while the bargadari system has ensured the security of the cultivators from eviction, it has also at the same time, made the absentee and non-cultivating landowners uninterested in investing in cultivation. Unfortunately most of the poor marginal or landless sharecroppers do not have the resources to undertake cultivation on their own. So in most of the time they depend either on the earnest money from the Money-Lenders, when the sufficient Bank loans are not available to them, or on their personal loan taken in the form of advanced crop or against the mortgage of family assessts or family labour. Thus the growth of organized forms of class conflict has not led to a major change in the existing class relation or the nature of economic dependence at the point of production. The broader social relations of dominance and subordination have certainly changes, but not the distribution of landownership or the nature of economic dependence of the sharecroppers/ bargadars.

\section{Looking through the Caste}

It could further be argued, that the principal social institution which is the center of the conflict and changes in most of villages in West Bengal including Rajoor Gram Panchayat area during last three to four decades is not class as defined by production relations, but caste. The organized forms of mobilization of poorer sections against the landed and wealthy could be seen as an outburst of lower caste protest against upper caste dominance. It could also be argued that in rural India, the class structure is subsumed within the structure of caste relation. It is fairly be stated, that, power in Rajoor Gram Panchayat area was once controlled by a few upper caste people, who were basically Non-Cultivating big landowners. In fact their non-cultivating status was once asserted by the social taboos or age-old traditional believe in view of their position in the caste-hierarchy. This taboos included Brahmin and Khystha of Hindus and Syed, Mirza, Chowdhury or Shaikh (Before the name) etc. among the Muslims. The changes of the last few decades could now be seen as the acquisition of local power by the lower caste people, and the organization of the lower caste people against the upper castes. Empirically it reveals that the main support base of Left Parties in West Bengal is still the lower caste people. Irrespective of religion, lower caste or people of lower strata of the society could more easily identify their interest with the Left politics and activities. Of course, this does not mean, that it would equally be reflected in 'Ballot Box'. Because there are number of extra-constitutional or super-constitutional factor that ascertain the battle of the ballot during process as we well as on the day/days of the election. Especially from 1996-97 onwards Political Parties of West Bengal started to adopt a new form of culture of "Election Politics". However, keep this apart, we have seen, that up to 1988-90, a majority of lower caste people, who were mainly landless and cultivating castes among both Hindus and Muslims used to support the Left Parties. Even during 1980-84 Panchayat Election, the local Congress candidates did not bother to campaign in the lower caste neighborhood since they assumed that the Congress had no hope of getting their votes. Up to 90 ' of the last century many upper caste people in Rajoor area or in most of the Villages in West Bengal branded the Left Parties as the party of the lower castes. It was even believed that the intention of Left Parties were to acquire power and to use it for pampering and indulging "Chhotolok" in local politics against the "Bhadrolok". There is no doubt that much of the feelings of antagonism in Rajoor as well as in other villages in West Bengal are expressed in terms of caste rather than of class.But this would still not give us an adequate explanation of the Political changes that we are investigating. There are too many complicating factors. First of all, the division of upper caste (mainly non-cultivating landowners and absentee non-cultivating landowners who lease out their lands to share croppers: explanation added by author.) / lower caste peasants (mainly Munish/ Mahinder, landless sharecroppers of Bagdi and lower caste Muslims and laborers of lower caste Bagdi goyala, who are considered as 'Ajalchal caste', that is, whose touch do pollute water for use by the people of higher caste: explanation added by author.) is too simple. While most of the upper castes, who resented the growing 
assertion of the poorer peasantry, used to describe it as the insolence of the 'Chhotolok'. It was the middle caste 'Ugra Kshatriya' or 'AGURI' and 'Sodgop' and trading castes, like, Karmakar, Bene, Carpenter, Das, Ghosh, Dey etc. whom we have described as an affluent/ middle rich peasant, Money Lenders, Traders, Artisans, who were the most aggressive in their campaign during 80 's and early 90 's of the last century against the lower caste or mainly 'Ajalchal' caste, like 'Bagdi', 'Muchi', 'Cheluti' and lower caste Muslims. But during that time there was no natural allegiance between them and pure upper caste on the question of aggressiveness. Because the upper castes occupy a vast range of large and medium land holding. All upper caste families are not traditionally big landowners. Nor was there an alliance among landholding middle castes against lower caste, along the lines of 'back word caste movements', like in other parts of India. The middle castes, we have seen, were greatly divided in terms of landholding, and at the beginning, they failed to organize themselves as political group with clearly articulated interest. But since mid of the 90's of the last century, anti-left Parties and middle caste group, gradually started to come closer to each other. Even then the most important aspect which makes a caste explanation difficult to sustain, is the clear evidence that, from 70's decade of last century onwards and even in the year 2012-13, the leadership of the organized movement of the poor and landless peasantry comes predominantly from the upper and middle castes. Most of the leaders, irrespective of Left and Right, are mostly from these castes and usually economically and socially better off and better educated than their supporters. There is, of course, new relation of dependence between the leaders and their supporters, but it would be simplistic, indeed wrong, to call this a new form of caste relation, because the democratization of politics in Rajoor Gram Panchayat as well as in most of the villages of West Bengal has meant the introduction of a new form of "public responsibility" in the activities of political leaders which makes their role qualitatively different from that of the upper caste "big men" of the past. Finally after 80 's of the last century, it may be noted that although the new conflict not only in Rajoor Gram Panchayat area but also in most other villages in West Bengal are often expressed in the language of caste but there has never been an explicit formal expression of caste demands in any of the organized form of politics in the area during last three to four decades. Although many of the earlier forms of social subordination expressed in terms of the caste hierarchy have been challenged and overthrown in recent years (leading to the charge that the 'Chhotolok' have become insolent), none of these changes have come about because of any explicit organization of caste demands. In fact, the explicit form of political mobilization in Rajoor Gram Panchayat area, as indeed in most other parts of West Bengal, is that of class rather than Caste.

\section{Rise of Middle Peasant and Its Impact:-}

There is more subtle variation of class antagonism in the sociological literature on agrarian movement which need to consider with due importance. This arguments divides agrarian society into a few broad categories:-

- Landlords (both non-cultivating and absentee landlords)

- Rich Peasants (specially cultivating landowners, who generally cultivate their lands under their own/family supervision by 'Munish/Mahinder'. Maintain plough and bulls and other traditional as well as modern instruments for cultivation in their own holding. By caste or class categories they generally belong to middle caste or class in the village). In some occasions they are seen to lease out a portion of their land to the sharecroppers.

- Middle peasant (this category includes cultivating landowners who in most occasion cultivate their land with their family labour supplemented by some hire labour as per requirements. They also 'lease in' to increase their aggregate of produced crop).

- Sharecroppers (they lease in lands from landowners and cultivate with their own plough and bull. In some cases they also 'hire in' the plough and bull from the landowners. Cultivation by 'hire in' instruments is reflected at the time sharing the crop with the owner). There are even some sharecroppers who own a marginal portion of land, which they cultivate either with own plough and bull or by 'hired in' plough and bull paying the cost for it through his labour. This marginal landownership help the family to increase the aggregate amount of crop.

- Landless sharecropper and labourer (this portion only 'hired out' their labour. They may actually be called rural proletariat). 
Each of these categories possess certain potentialities in view of their own class and social position. From this standpoint, poor peasant are considered the most reliable ally for the revolutionary proletariat, and middle peasant can be brought over to cause of revolution, if they are guided by suitable political ideology and well organized political party. The forces which opposes any sort of agrarian protest movement or demand are the landlords and the rich peasants. The principal driving force in the villages is the vast numbers of landless labourers. Middle peasants and sharecroppers have actually have the capacity to lead any sort of demand movement at least politically. Thus in view of this class analysis and the potentialities of different classes, the middle peasants and sharecroppers with marginal amount of land in possession, are considered a crucial force in the initial stage of peasant resistance during sixties' to early nineties' of the last century against the 'big landowners' and 'rich peasants'. Although it is also fact that due to fragmentation on land causes by separation of family unity and estranged land holding, are also an obstruction for consolidated peasant movement against 'big non-cultivating landowners' and against the 'absentee landowners' and 'rich peasant'. It is still evident as it was during 1984-1986 period the poor and marginal 'landowner sharecroppers' and 'landless labourers', because of their material conditions, depends heavily on their landowners for their livelihood as well as for cultivation. Even the easy access to different governmental socio-economic rural Programme is not fully open to them. So they do not possess an economic base on which they could stand against their landowners or rich peasants unless they are provided with external help. Only the middle peasant and a section of marginal landowner sharecroppers, who possess a certain amount of land as their means of subsistence, enjoy the minimum autonomy to defy the landlord and to organize the proletariat against the dominance of 'noncultivating landowners' and 'rich peasants'. Eric Wolf ${ }^{(3)}$ and Hamza Alavi ${ }^{(4)}$ in their analysis of the character of the middle peasant have also revealed such a conclusion.

Our knowledge of the principal movements over last four/ five decades in Rajoor Gram Panchayat area as well as in other villages makes the roles of middle peasants worth considering. Various movements against the dominance of the traditional big men and rich landowners/peasants show that at the initial stage, even during seventies' to nineties' of the last century, leadership was made up mainly with cultivating landowners, who carried along with them a large number of poor sharecroppers/ bargadars and landless labourers. At the initial stage, the movement and protests were to redress some social grievances of the lower caste people. But gradually since 1984-85 both the trend of movement and nature of leadership began to shift from its original point of emergence. Movements were started to organize on economic demands such as wage increase, surplus land occupation, barga recording and establishment of barga rights, and on the other hand new forces of leaders started their fight to acquire power in the local panchayat institution.

Our group of middle peasants consists of those who own some amount of land which they till themselves or with the help of some 'hired hands'. Even they are seen to 'lease in' some lands of noncultivating absentee landowners. Generally their economic position is more or less stable in comparison with small peasants who use family labour to avoid 'hired in' labour and at the same time 'lease in' maximum amount of land to cover their deficit of net crop produced out of their marginal portion of land ownership.

In this connection, we may recapitulate our experience we gather during 1984-86, when we first came here as a participatory observant in this locality. When the Kisan Sabha was set up in Rajoor area in 1965-67 to lead the peasant movement against big landowners, it was primarily led by young educated people, who came from the relatively well-to-do peasant families. The activities of the Kisan Sabha generally focused on campaigns against the abuses of 'big landowner'. The participants were mainly recruited from the poor sharecroppers/ bargadars and the vast number of landless labourers. At the initial stage the leadership was composed almost entirely of young educated people from 'owner cultivator' families. A few of them, in some cases, belongs to the category of small non-cultivating landowners. Gradually since 1979-80, the few landless people from 'Bagdi' Chasa' etc. 'ajalchal' caste laborers were seen to be the part of such political groups. Actually their proportional majority was the prime cause of their inclusion as well as their importance in the group.

This account shows two important aspects of the peasant movement in West Bengal, especially in Rajoor Gram Panchayat area. Firstly, the poor and landless peasants entered the opposition movements against the 'big men' of this locality (especially) after the ground was prepared by the relatively better-off sections (cultivating landowners) of the peasantry. Second, the movement soon came to be led by Left Political Party of West Bengal, even when the Kisan Sabha was the leading organizer of the movement. In fact the activities of the Kisan Sabha were decided by the Left Party. Among the leaders of these two organizations, there were only

DOI: $10.9790 / 0837-2203060110 \quad$ www.iosrjournals.org $5 \mid$ Page


a few members from the poor peasants' categories. A majority of members were from middle class of cultivating landowners along with a few who were sons of 'non-cultivating landowners' and 'rich peasants'.

Our observation during 1984 to 1986 shows that up to 1977, these movements had few tangible sources. In most cases, they were suppressed by the powerful landowning interests with the help of local agencies of state machinery. It was only in the brief spell of United Front rule in West Bengal that the local organizer and supporters felt confidence enough that the State agencies of repression would not be directly used against them. What these scattered movements achieved, however, was a sense of solidarity between the Left leaders of Rajoor area and the poor landless peasants, within the framework of local Kisan Sabha and Party Organization. At the same time a vague frame, regarding the availability of 'state protection from its coercive forces' and 'the way of getting the demands fulfilled' was articulated in their sub-conscious understanding. ${ }^{(5)}$ After 1977, however, we have seen that the movement has attempted to go no further than to realize the recommendations of the Government. Except for an initial period of confrontation, these demands have not provoked any major clashes either with the Government or with the 'rich landowning' section. In many cases, we witnessed during our first visit of the area in 1984-1986, the leadership even went into compromises with the 'landowning section'. In spite of that whenever the party or Kishan Sabha called for a movement, the poor and landless people were responded. But gradually the leadership, the bulk of which consists of the middle class of peasants, have refrained from raising new demands on behalf of the poor and landless peasantry and have reserved their mobilization efforts mainly for electoral purposes. With the old form of dominance of 'big men' largely a thing of the past, the political leadership of the left has not seen it proper to go into confrontation with the 'rich cultivating landowners' and trading groups of the village. There is another problem which complicates an explanation of the change, in village simply in terms of the role of middle peasants. The 'middle peasants' do not form a very stable group in same way as poor and landless peasants do. Most of the new opportunities of mobility afforded by education, non-agricultural employment, trade etc., are utilized principally by members of this group. One or the other of those opportunities could significantly alter the economic position of a family in relation to others in the same strata. Not surprisingly, there were tremendous pressures, working on the local political leadership from the middle class for access to these scare opportunities. These pressures, however, often severe to divide rather than unify the middle peasants as a strata with distinct class interests. Indeed, there was so much heterogeneity within the middle peasant group in terms of economic position (ranging from small non-cultivating landowners to owner-cum-sharecroppers) and social standing (a whole range of castes and educational qualification will be found within the group) that it was virtually impossible to define a clear political role for the group. ${ }^{(6)}$ In its relation to other classes, the evidence from Rajoor area suggests a very ambiguous role of the middle peasant group. One section is clearly identified as the political leadership of the bulk of the poor and landless peasants. There is another section, which is strongly opposed to the political tactics of the Left Parties. Most of them seem to vacillate in their electoral support for Left and other Rightist Parties. One section seems to be ideologically committed to the removal of oppressive social and economic practices operating upon poor and socially depressed section of the people. Other are annoyed that the growing assertion of the poor might mean greater insecurity for their own 'middle class' position in society. All these different political and social motivation can be seen to operate among the 'middle section' of the peasantry in Rajoor and also in other villages.

\section{Electoral Politics And Changes:--}

The basic purpose of this study was not to show that the Rajoor as well as other villages in WestBengal have changed; they obviously are changing. The intention of our revisiting the area was to identify the main structural changes and consequences of political action of individual and group to modify, overturn and replace existing relation of power, first during 1995 to 2003 and then 2008 to 2013. Although we have repeatedly discovered during the course of our first visit during 1984 to 1987, and then during our revisit of the same Panchayat area in 2013, that the new traits of changes of political allegiance from left to anti-left started its sprouting from 1994-96. We are also convinced that these changes through electoral politics did never attribute much to the internal transformation of social relation within the village, but certainly there was an impact of external forces represented by political organization and state agencies. And yet, in terms of the 
relations of production, up till now we have not found any dramatic transformation in the exploitative relation between classes within the production process. Then what significance do we attach to the many apparent changes that have taken place in recent past?

It is our contention that the significance of these changes can be best appreciated by taking a historical view over last fifty to sixty years or so. That has been the method of our study. What have we found?

We have found that the root of this change may be found, first of all, a clear and unambiguous change of the traditional dominant group in the village in the space of the last fifty years or so. The conventional historiography of modern India tends to put final decline of the Zamindari classes in the phase of anti-feudal agrarian movements in the last days of colonial rule. At aggregate level of large historical processes, this is true, and certainly so for West Bengal. However, it is misleading to take the legal promulgation of Zamindari abolition in the years after independence as the nail in the coffin of Zamindari power. In numerous parts of India, as indeed in West Bengal, Zamindari power continued to thrive under the new framework of adult franchise, representative politics, planning, and rural development. We have seen in the case of villages of Rajoor Gram Panchayat areas, how the older Zaminders families continued to exert their social and political dominance up to the mid of 1960 's, through the local governmental bodies, with the close support of the local bureaucracy and police and indeed as the local vote bank to the ruling 'National Congress' both at the State as well as in the Centre. Ultimately their power was eroded, creating a condition of change of state politics in 1977 and paved the way of changes in rural West Bengal in 1978-79 through three tier elected Panchayati Raj system. A principal aspect of the change since 1977-79 is the final and irreversible of the older forms of Zamindari power.The second aspect of the changes was related to the rise of political opposition to the dominance of bigmen of the villages. This movement was primarily based upon the support of the poor and landless peasants and its form was largely determined by the political organization of C.P.I. (M). As a result of this particular political form at the village level, the event of the functions and power of Panchayat and its leaders became connected with the fluctuation in the position of the C.P.I.(M) in the politics of the state of West Bengal. In fact local government both at corporation or Municipality level or at Panchayat level came under the control of C.P.I.(M) led Left Front Government. In absence of any strong opposition in the arena of State politics, Left Party led by C.P.I,(M) began to enjoy the opportunities of distributing welfare benefits in exchange of unquestionable support and allegiance of majority of poor and landless peasants, either directly to the party member or to the party supporters and faithful sympathizer, partially ignoring the greatest need and administrative impartialities in judging the eligibility. This partiality in pursuing mundane social democratic equality gradually exposed the failure of Left party led government to fulfill the expected degree of anti-poverty welfare activities. Sri Balaram Karmakar, Ex Head Teacher of Rajoor High School, very slowly and in very lean voice reminded those days when we visited him during our second visit of the area, "From 1994 onwards new leaders of C.P.I.)M), most of them were local, started the 'politics of dividend'. Middle class rural elite was the best beneficiary of that process. This also created 'ideological fragility' in left politics, and ultimately that became the cause of creating the ambiance of 'absolutism' and 'politics of intolerance'. That subsequently created a solid base of ruthless politics and 'machinist cruidility' (famous political Bike Bahini - added by author) among lumpen poor and surplus labour of the villages". (7) One way of looking at this process would be to see it as simple mobilization from the top. In other words, C.P.I.(M) was the main organizing center with active political leadership who were stretched out into the countryside by the whip of the top State and District level leadership, propagating its ideology and support through a series of alliances with different groups of rural people based upon 'primordial' loyalties such as caste, kin, or locality. Here Sri Hrishikesh Ghosh, one time (during Seventy's and early eighties of the last century) local leader of C.P.I.(M), now detached from active politics, only supports the Left ideology, told to us, "When we started active politics in 1970-72, then we had our own "Self Focus". It was also enthused by the Party Leader of District. They frequently used to come to our villages to resolve any dispute of poor peasants, sharecroppers with the landowners. Their attempts were to protect the interest of the poor peasants who were our main ally. But gradually we lost our 'focuses'. Now our Party has become the party of Leaders not of the cadre." (8).

However, C.P.I.(M) led Left Front Government started a positive move in 1980's onward towards empowering the local Panchayat structure as an administrative body. Although there was ideological and political manipulation to strengthen the authority in the village politics, but that too were initially used to activate the process of decentralized planning and implementation of them with initiative of Panchayat 
administration. But very soon Party leaders and government took the reverse track. Gradually Panchayat and the manipulated local leaders of the party turned into mere local level bureaucrats. This ultimately threatened the democratic values and slowly took a vulgar form of self-oriented power based politics. The root of this reverse movement slowly but steadily gave birth to a new ultra-rightist politics under the effective leadership of rich cultivating landowners actively backed by non-cultivating landowners. It was also due to the political collapse of movement of decentralization at the village level. As a consequence, a new trend of positive attempt of nurturing a new culture of political absolutism, which gradually started to develop, receded, the previous attempt of empowering the poor and landless peasant. Left parties, at once, initiated their politics of mobilization, with the hope of empowering the poor and landless peasants, against the big-men politics. But why this shifting was made? Underlying this framework was the assumption that peasants are ignorant of the form and issues of politics, that their ideas and beliefs are entirely 'traditional' and 'resistant' to all changes. And that their dependence on the patrons make them susceptible to this absolutist manipulation in politics. Initially this 'mobilizing manipulation' gave positive result to the C.P.I.(M) up to 2003-04. C.P.I.(M) party started to follow two tactics. On the one hand, extended their collaborative attitude and efforts to the rural elite and help them to restore their traditional power, on the other hand, they successfully hold the rural people's loyalty, at least up to 2005-06 giving them an unwritten assurance of maintaining their economic survival through land 'patta', public 'doles' under various schemes. This declining trend of Left Party became evident from 1993 onwards. In 1993 Panchayat Election a serious blow initially came from within the LF, when RSP threatened to break the monolithic unity of the front on the 'agricultural question'. This opened up the opportunities to the opposition, to swing the politics in their favour. This ultimately implicates the vulnerability of C.P.I.(M)'s influence and its mythical invincibility among the poor and landless peasants. One of the basic reason of decline of C.P.I.(M) was its failure to hold the unity of the party machinery, which was gradually losing its discipline and ideological intentness. But up to 2003-05 there was no viable opposition against its invincible march for power. However, when it started to wane its discipline and intent cadre commitment, it became bound to rely on machinery of local leaders to keep their support base in the villages. "Even in exchange of the help they sought from those middle class leaders, the Party Leadership began to overlook many of their misdeeds and their unwanted links with the anti-social elements". ${ }^{(9)}$

In fact from 1995-96, the traditional 'left' inclination of keeping the village vote bank under intense observation began to shifted towards the newly liberated scope of expanding the industrial sectors. The common poor and landless peasants smelt it from the behavior of the village leaders. Even they started to perceive that during last thirty or so years enough opportunities were not created for them to enable them to build up their capacity, even the opportunities for education were not spread for all. Our observation during the period of our revisit show a strong grievances especially among poor lower class and among Muslim community for increasing tendency of social discrimination, the eradication of which was once the main social and political functional agenda of C.P.I.(M) leadership. During our casual gossip on $22^{\text {nd }}$. May 2013, we saw a deep tone of dejection in Afgar Ali's voice, who told us, "What has happened for us. Still we are over casted with the same darkness, as we were in the past. But now we have understood that this is not our way of improvement. Still we are depended on our 'babus' who are giving us their land for cultivation. Without which we have nothing to do." (10) One of the political commitment of C.P.I.(M) was decentralization of village planning, that ultimately misdirected by the local leaders, and became the cause of creating a new privileged middle class in the village, who enjoyed the creamy layer of it leaving the residue for commoners. During the time of our re-visit of Rajoor Gram Panchayat in 2013 we posed this question to some villagers like Afgar Ali etc. as well to some Panchayat leaders. They, with surprise, expressed their ignorance about it. They said, only on few occasion, panchayat leaders as well as C.P.I(M) party leaders sought their opinion on probable place for 'tube well erecting' or regarding renovation and repairing of any village morrum road. In fact neither Panchayat leaders nor the leaders of the political party showed any enthusiasm to incorporate the common villagers in the process of preparing decentralized planning for them. Strong manifestation of elitist mentality was the main barrier to put confidence on the poor general people and landless peasants. Extreme self-reliance of political leaders created a false notion and myth among them that only perpetual of political power of C.P.I (M) can serve the purpose of the poor.In fact the Left political ideology led by C.P.I.(M) was the main catalyst for the growing awareness among the poor peasant of Rajoor that it was possible for them to assert their rights. This was the actual form through which C.P.I.(M) won the electoral politics. So when this favorable condition began to shift from the rural poor 
to elite leaders, naturally environment of disbelief and lack of unconditional electoral support got a new boost in the village against the existing ruling party. Simultaneously a new way of entering into the village politics was opened up.

\section{Our Observation:}

So far we have tried to indicate the implication of 'manipulative politics'. But at a certain point, it is necessary to go beyond this simplified analysis. The politics of Rajoor Gram Panchayat today is not simply determined by the alliance making process of political entrepreneurs, but there is also an organizational factors which binds together the active cadre and/or lumpen political activists with the larger domain of State politics. Along with that, the active political choice of the villagers, weighing the various alternatives before them, choosing their leaders and withdrawing support, if need be, become the other factors of changing their belief on leaders and electoral support. These were actually the effect of democratization of politics through increasing participation of common people in the affairs of political institution like political parties, Panchayat and election process. This knowledge helps them to understand the intricacies of the State politics and political activities of the political leaders vis-a-vis their own interest and position.This has also another implication. Even after independence poor peasants and landless sharecroppers of villages earned their livelihood under aegis of Class power, exercised by the 'big-men' and 'Zaminders'. Neither their demands nor their discontent were came under the direct consideration of the state domain. 'Big-men' and 'Zaminders' used to exercise their power under their rule and dominance. Although the National state, tried to bring a break through this aegis of 'big-men' and 'Zaminders' dominance by implementing the laws like abolition of Zamindari Rights followed by 'land reform' legislation. National State also tried to transform the class power through institution like Panchayati Raj System. But if we look up to 1960-65 we will find that attempt was fragmented and deeply compromised by the electoral compulsion of accommodating those wielding effective power in the villages. But, surprisingly, from the very beginning of the journey, the National State power did never make any positive and radical attempt to transfer the agrarian relation. Instead, it brought the politics of 'big-men' and 'Zaminders' within the purview of the organized political election and political parties. Parallel to this, it also made the device for the 'big-men' to extend their dominance and authority over the majority poor peasants and landless sharecroppers. Panchayat, Community Development etc. were the facets of that device. In West Bengal we witnessed a different impact on power structure after inclusion of political election and political parties. There was a growing awareness among poor peasants and landless sharecroppers in Rajoor. These extension of electoral politics and activities of political parties made it possible to assert their rights and to do way with several oppressive aspects of social and economic exploitation. They only expected the minimum assurance from the political parties and organization that the state would not come down on them. These gradually become the form in which the electoral politics in West Bengal started its operation.But this electoral politics, although brings 'democratization' in political process, but has not resulted in any significant change in production relation as such. Still in twenty-first century poor peasants and sharecroppers are virtually dependent on landowners, that small absentee landowners have not been eliminated, that relatively affluent peasants are still seeking ways of enrichment through trade, hoarding, money lending, and that no new forms of production organization have so far emerged.State and political parties operate in the village politics and fight for electoral strength may have two alternatives for the overall development of poor peasants and landless sharecroppers. One, attempt may be made for capitalist development of agriculture by implementing large scale farming. Or secondly the condition may be improved by evolving high yielding varieties for increasing the agricultural productivity beyond providing a basic minimum subsistence for the small peasants.But left parties, specially C.P.I.(M) during last 25 to 30 years of their dominance, and then Rightist party under the leadership of TMC only tried to mobilize the support of poor peasants by providing them the assurance of security programmes in agriculture, education, employment and health. As a result, the poor peasants also swing like a pendulum, from left to right, to find out the alternative like 'social advantage' or 'avenues of economic power' from the politics. The TMC, assuring the social and economic assurance, used the rural surplus poor peasants and landless sharecroppers as their reserve 'Bahini' against C.P.I.(M). ${ }^{(11)}$ Thus the tradition of state patronage continues as an instrument for retaining electoral support. This mechanical base of "support politics" often creates problem of allocation of advantages provided by the State, which in turn raises the charges of unholy partisanship and difference among poor peasants and landless sharecroppers with the political parties. At the initial stage in seventies, panchayat institution embodied the form of solidarity of rural poor and landless sharecroppers against the 'big-men' dominance. Gradually from

DOI: $10.9790 / 0837-2203060110 \quad$ www.iosrjournals.org $9 \mid$ Page


the later part of eighties of last century, it got a new legal and constitutional form under the direct patronage of the State. And that in turn opened the avenues of pursuing individual enrichment and individual self-interest. In other words, by the end of eighties of the last century, the basic forms of its politics started to get a new shape of bourgeois state order. So in the course of its way under the direct leadership of C.P.I.(M), it became a paradox for the party and the movement which was ideologically committed to overthrow the bourgeois state. Thus acting as an instrument of the democratization of rural politics, and yet failed to provide an alternative social order, 'left ideology' in fact performed a crucial role in consolidation of bourgeois order and extreme rightist force with machinist support.

\section{REFERENCES}

[1] A part of my observation and narration of our experience, may be seen in my previous article, 'Historical Context of Political Change in Rural West Bengal: A Study of Seven Villages in Bardhaman' in Economic and Political Weekly, Vol.XXVII No.13, March 28, 1992, pp.647 to 658.

[2] See. Nripen Bandhopadhyay, Evaluation of Land Reform Measures in West Bengal: A Report, Centre for Studies in Social Sciences, 1983.

[3] Eric wolf, Peasant Wars of the Twentieth Century, London 1971, pp. 290-2.

[4] Hamza Alavi, "Peasant And Revolution" in K.Gough and H.P.Sharma (ed) Imperialism And Revolution, New-York 1973

[5] Sri Hridyananda Ghosh (whom I met during 1984-86) made this comment to me when I met him during my second visit on $24^{\text {th }}$. May 2013.

[6] See, Jacques Pouchepadass, 'Peasant Class in Twentieth Century Agrarian Movement In India', in E.J.Hobsbawn, W. Kula,et.al.,(ed) Peasant History, Oxford University Press, 1980, pp. 142-53.

[7] We met Sri Balaram Karmakar in his residence on $20^{\text {th }}$. May 2013, now he has retired from his service. First we met him during 1985, when he was in service in Rajoor High School.

[8] We talked with him during the time of our revisit on $20^{\text {th }}$. May 2013 and again on $22^{\text {nd }}$. May 2013. He talked with us on many issues of shifting of party focus.

[9] Sri Balaram Ghosh, narrated this story to us, when we met him on $20^{\text {th }}$. May 2013, during our revisit of this area.

[10] Asgar Ali, is a landless Sharecropper of Rajoor, whom we met during our first visit of this area during 1984-86. He was then one of the active supporter of C.P.I (M).

[11] Abu Taher Ali, Teacher of Rajoor School narrated this story to us on 29-30 ${ }^{\text {th }}$. May 2013. He was an active member of C.P.I.(M) local committee, but due to some personal reason, he did not renew his membership from 2011. Even then, he still maintains relation with the District Party Leaders. 